\title{
Coir Fibre: A Sustainable Engineering Material for the Caribbean Environment
}

\author{
Abrahams P. Mwasha ${ }^{1}$ \\ University of The West Indies
}

\section{ABSTRACT}

One of the most inventive, sustainable strategies used in ground engineering is the substitution of biodegradable materials for non-biodegradable materials, particularly in situations where short-term ground improvement is needed. Biodegradable materials such as vegetable fibres have excellent engineering properties that could be used in the construction industry to enhance filtration, drainage and reinforcement. Two of the most important properties of vegetable fibres used for soil reinforcement are their high initial tensile strength and environmentally-friendly qualities. This paper investigates the timedependent behaviour of basal-reinforced embankments erected on soft ground using biodegradable geotextiles, such as coir fibre, derived from coconuts, as reinforcing materials. An analytical model for soil reinforcement, which incorporates changes of foundation soil strength over time due to consolidation, is analyzed using the GEO5 slope stability computer software. The initial strength of the fibre reinforcement required to achieve a specific factor of safety is calculated.

\section{INTRODUCTION}

Vegetable fibres have long been used by all cultures for multiple purposes: cordage, matting, weaving and reinforcement of building materials. In the Middle East, the ancient Babylonians and Mesopotamians, (9000 B.C. to 3000 B.C.) used welldeveloped masonry technology to build large structures using brick, such as the temple at Tepe Gawra and the ziggurats at Ur and Borsippa (now known as Birs Nimrud, Iraq), which stood up to 26 metres high (Vogel, 2004). The Agar-Quf Ziggurat, located about five kilometres north of Baghdad, was constructed of clay bricks reinforced with mats of reed laid horizontally on a layer of sand and gravel with vertical spacing varying between 0.5 and 2.0 meters (Jones, 1996). The reeds used to reinforce the ziggurat were in the form of plaited ropes approximately $100 \mathrm{~mm}$ in diameter which passed through the structure. According to Jones, the Great Wall of China, parts of which were completed circa $200 \mathrm{BC}$, also contains examples of reinforced soil.

Natural fibres were used in construction between 5000 and 3000 B.C. when dwellings were built with mud or clay bricks reinforced with reeds or straw.

The book of Exodus (5:6-9, Authorized Version) states that in Egypt, both straw and clay were used in the process of brickmaking; the straw was the bond which held

\footnotetext{
${ }^{1}$ Abrahams P. Mwasha, Lecturer, Department of Civil and Environmental Engineering, Faculty of Engineering, University of The West Indies, St. Augustine Campus, Trinidad and Tobago.

E-mail: amwasha@eng.uwi.tt

Acknowledgments: The author is grateful to the Trinidad and Tobago Government Research Fund for the financial assistance to make this paper possible.

How to cite this article in APA style (7th ed.): Mwasha, A. P. (2009). Coir fibre: A sustainable engineering material for the Caribbean environment. The College of The Bahamas Research Journal, 15, 36-44. https:// doi.org/10.15362/ijbs.v15i0.108
}

(CA.P. Mwasha, 2009. Journal compilation (CThe College of The Bahamas Research Journal, 2009. 
the brick together. However, verse 7 has led to some conjecture concerning the use of straw in making brick: some people support the idea that straw was used only if the brick was burnt in a kiln, whilst others believe that the bricks were made of clay and straw kneaded together, and not kiln-burned, but thoroughly dried in the sun (Mwasha, 2003).

Within the last 50 years, there have been rapid developments in construction techniques, analytical methods and the development of materials for use in ground engineering. One of the major techniques developed is soil strengthening or reinforcement, whereby synthetic polymeric (petroleum derived) materials are integrated with geological material to provide stability (Holtz, 2001). However, most synthetic polymeric geotextiles are not biodegradable; therefore after their service life they must be removed to a disposal site.

As a result of increasing environmental awareness worldwide, there is need to consider the potential for the use of biodegradable geotextiles (Mwasha, 2008) rather than synthetically manufactured materials, particularly in situations requiring short-term soil reinforcement. An example in Trinidad and Tobago using biodegradable material is the Beetham Highway in Port of Spain, which was constructed on swampy soil between 1955 and 1956 (Anthony, 1997). This major highway was reinforced using mangrove planks.

The most important property of vegetable fibre, especially for soil reinforcement, is that it possesses high initial tensile strength. However, widespread use of vegetable fibres in ground engineering has not happened due to the very biodegradability of these fibres and the existence of chemical fibres, which are superior in terms of durability to vegetable fibres, where biodegradability is not important.
Considering the biodegradable nature of vegetable fibres, their technological design and use in ground engineering should be well elaborated to match the working environment. This paper investigates the potential for the use of vegetable fibres such as coir fibre, in ground engineering applications that require biodegradable materials. Coir fibre is material extracted from the tissues surrounding the seed of the coconut palm.

\section{MATERIALS}

Fibre-producing plants such as cotton, bananas, sugarcane, cannabis and coconut palms, are abundant in Caribbean Islands. The coconut palm is grown for decoration as well as for its many culinary and non-culinary uses. Virtually every part of the coconut palm can be used for some purpose. The byproduct of the copra extraction process is coir fibre which is usually discarded as waste. These fibres have excellent engineering properties.

\section{Coir fibre geotextiles}

Coir fibre geotextiles are made up of the coarse fibres extracted from the fibrous outer shell of a coconut. The individual fibre cells are narrow and hollow, with thick walls made of cellulose. They are pale when immature but later become hardened and yellowed as a layer of lignin is deposited on their walls. There are two varieties of coir: brown and white. Brown coir is harvested from fully ripened coconuts. It is thick, strong and has high abrasion resistance. It is typically used in mats, bushes and sacking. Mature brown coir fibres contain more lignin and less cellulose than fibres such as flax and cotton, and the fibres are resilient, strong and highly durable but less flexible than flax and cotton (Bismarck et. al., 2001). Coir fibres are made up of small threads, each about $1 \mathrm{~mm}$ long and 10 to 20 micrometers in diameter. The coir fibre is relatively water-proof and is one of the few natural fibres resistant to damage by salt water. Fresh water is used to process 
brown coir, while sea water and fresh water are both used in the production of white coir.

White coir comes from the husks of coconuts harvested shortly before they ripen. These fibres are softer and much weaker than brown coir. The fibres are extracted by being suspended in a river or water-filled pit for up to ten months. During this period a microorganism breaks down the plant tissues surrounding the fibres to loosen them (retting process). Segments of the husk are then beaten by hand to separate the long fibre which is subsequently dried and cleaned. The cleaned fibre is then ready for spinning into yarn using a simple one-handed system or a spinning wheel.

\section{Vegetable Fibre vs Synthetic Fibre Geotextiles}

There are numerous ground engineering situations where the critical period for stability is immediately after construction, or shortly thereafter, e.g. in the case of any form of 'foundation loading' of free-draining or slow-draining soils. In such situations it is common practice to incorporate geosynthetic basal reinforcement to provide an additional stabilising force. If the foundation soil is slow-draining then loading of the ground will create excess pore pressure within the foundation. Subsequently, with time, pore water in the foundation will migrate from beneath the loaded area and the shear strength of the foundation will increase. Hence the stability of the system will improve in time and so the stabilising force necessary, which is provided by the geosynthetic textiles, will diminish. After some time (typically between a few months and a few years) the whole system will be completely stable with little or no assistance from the geosynthetic material (Mwasha, 2005).

Coir fibres are the ideal 'raw material' which could be used to manufacture these shortlived geotextiles since they biodegrade over time. There are a wide range of natural fibres available and these exhibit very different strength and durability characteristics as illustrated in Table 1. Coir fibre subjected to cycles of wetting and drying would lose only around $8 \%$ of its strength after 6 months, 20\% after 12 months and $30 \%$ after 2 years, whereas with flax the corresponding strength losses would be $45 \%, 60 \%$ and $90 \%$ respectively (Pritchard, 1999).

Pritchard (1999) found that VFGs (vegetable fibre geotextiles) have superior soil reinforcement properties when compared to mid-range synthetic geotextiles. This is because most vegetable fibres have high initial tensile strength.

Table 1

Tensile Properties of Novel Designer Vegetable Fibre Geotextiles

Major properties

\begin{tabular}{lrrrr}
\hline Geotextile type & Load $\mathrm{kN} / \mathrm{m}$ & Strain (\%) & Density $\left(\mathrm{kg} / \mathrm{m}^{3}\right)$ & Thickness (mm) \\
\hline Woven sisal warp/flax weft & 179.80 & 14.05 & 1.84 & 5.60 \\
\hline Woven coir warp/flax weft & 60.97 & 9.64 & 1.28 & 3.60 \\
\hline Woven sisal warp/coir weft & 113.00 & 26.57 & 1.65 & 7.50 \\
\hline Woven 6x1 weft rib sisal warp/coir weft & 170.60 & 8.35 & 1.60 & 12.10 \\
\hline Woven coir warp/weft & 19.76 & 28.12 & 1.11 & 8.00
\end{tabular}

Note. Adapted from Vegetable fibre geotextiles, by M. Pritchard, 1999, Manchester, Eng.: Bolton Institute, Manchester University. 


\section{AN ANALYTICAL MODEL AND TRANSIENT PORE PRESSURE ISOLINES}

The time-dependent behaviour of an embankment constructed on soft soil was analyzed numerically by conducting a parametric study. The physical values were selected for the study after an intensive literature review.

The embankment was composed of freedraining material which was assumed to be $3 \mathrm{~m}$ high. The depth of the foundation soil was 3 meters. The foundation was fully saturated and the groundwater was at ground level.

Following Mwasha (2006), transient pore pressure isolines are used to represent the dissipation pore pressure with time. As shown in Figure 1 (below), the transient pore pressure isolines are formed by points on the isochrones. These transient pore pressure isolines were used as inputs in the GEO5 computer program (1999-2007) for analyses of slope stability.

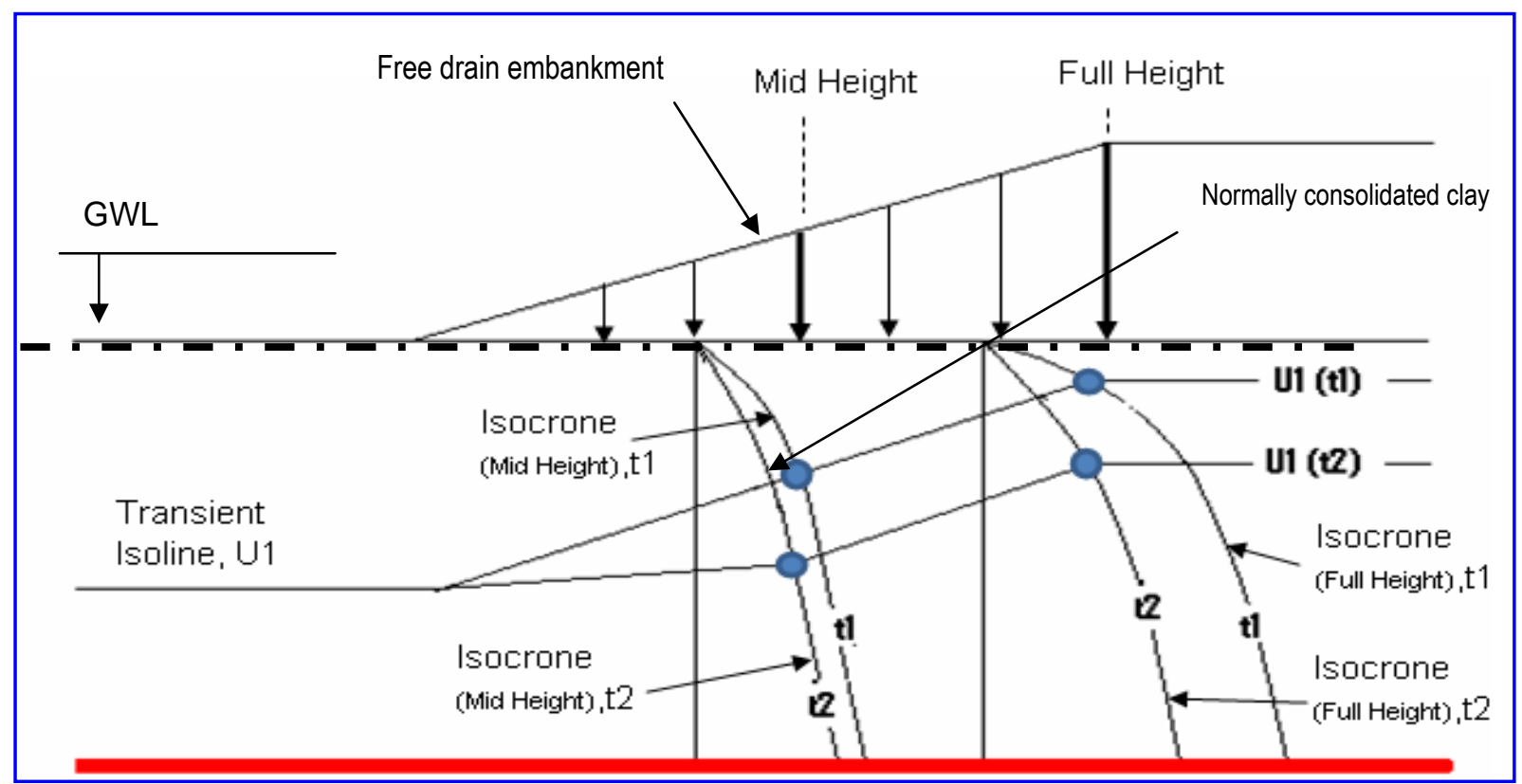

Figure 1: Time-dependent behaviour of an embankment

TIME-DEPENDENT BEHAVIOUR OF REINFORCED AND UNREINFORCED SLOPES

\section{Analysis of Unreinforced Slopes}

For an embankment constructed on soft ground, the shear strength of the foundation soil increases with time. To show how this increase in shear strength will affect the stability of slopes, the GEO5 computer program was used to analyze different slopes with varying foundation and embankment parameters. A list of the parameters analyzed is shown in Table 2. 
Table 2.

Typical Values of the Relevant Parameters for Full Parametric Study

\begin{tabular}{|c|c|c|}
\hline Typical steepest slope (V:H) 1:1 to 1:5 & Embankment & Soft Soil \\
\hline Typical shear strength parameters & $c^{\prime}=0\left(\mathrm{kN} / \mathrm{m}^{2}\right), \phi^{\prime}=35^{\circ}$ to $41^{\circ}$ & $c^{\prime}=0, \phi^{\prime}=14^{\circ}$ to $26^{\circ}$ \\
\hline Range of bulk unit weight & 18 to $20\left(\mathrm{kN} / \mathrm{m}^{3}\right)$ & 15 to $20\left(\mathrm{kN} / \mathrm{m}^{3}\right)$ \\
\hline Slope range chosen for analysis (V:H) 1:2 to $1: 5$ & Embankment & Soft Soil \\
\hline Selected shear strength parameters & $c^{\prime}\left(\mathrm{kN} / \mathrm{m}^{2}\right)=0, \phi^{\prime}=35^{\circ}$ and $41^{\circ}$ & $c^{\prime}=0, \phi^{\prime}=14 \circ$ to $26^{\circ}$ \\
\hline Selected bulk unit weight & $18\left(\mathrm{kN} / \mathrm{m}^{3}\right)$ & 15 to $22\left(\mathrm{kN} / \mathrm{m}^{3}\right)$ \\
\hline
\end{tabular}

Note. $c^{\prime}$ is the shear strength of the foundation and embankment soils. $\varphi^{\prime}$ is the angle of the internal friction; and V is the vertical rise, and $\mathrm{H}$ the horizontal distance of an embankment.

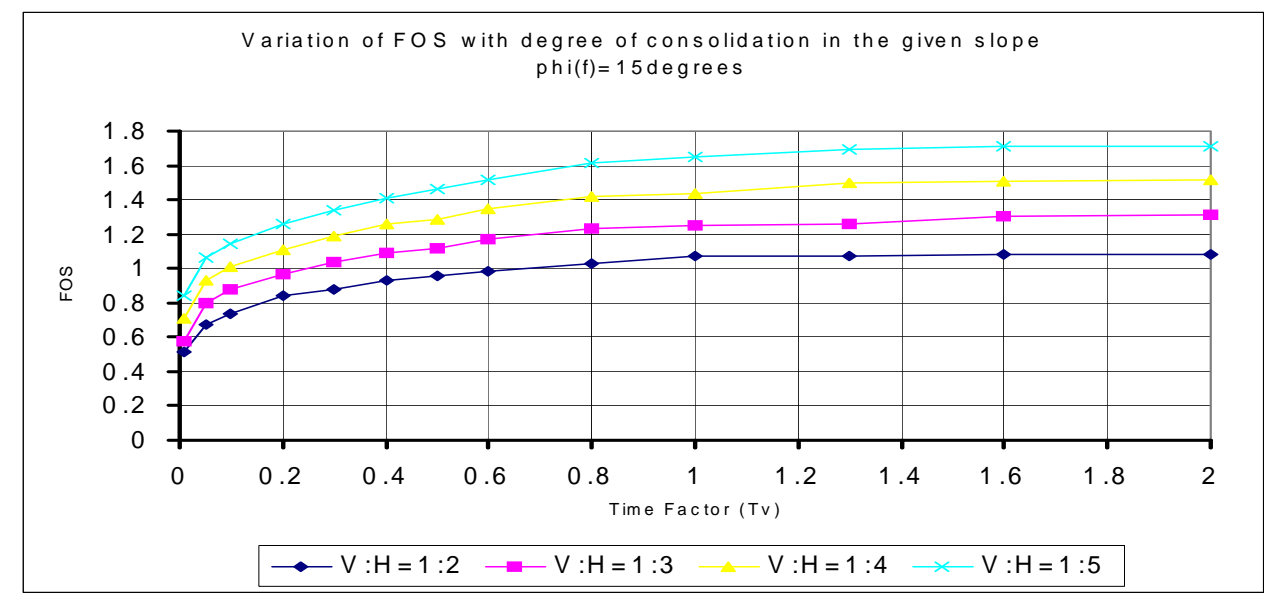

Figure 2: Effect of consolidation on slope stability

The effects of slope geometry and foundation and embankment parameters were investigated by observing the change in Factor of Safety (FOS) over time. A large number (3500) of critical slip circles were analyzed, for slopes $\mathrm{V}: \mathrm{H}=1: 2$ to $1: 5$, to examine the effect of consolidation for Time Factor (Tv) values from the end of construction $(\mathrm{TV}=0.00)$ to the end of consolidation $(\mathrm{Tv}=2.00)$. The resultant values of FOS were plotted against $\mathrm{Tv}$ in Figure 2, which shows that, as TV increases, the degree of consolidation increases and the stability of all slopes increases regardless of the slope angle. In fact, this increase means that even though all slopes are initially unstable at $\mathrm{Tv}=0$, i.e., all slopes initially have FOS less than unity, they subsequently acquire FOS in excess of unity, i.e., they become stable with consolidation. For a particular slope, the increase in Factor of Safety is due to an increase in the resisting moment, because consolidation enhances the shearing resistance of the soil. Figure 3 presents the same information as in Figure 2, exchanging $\mathrm{Tv}$ with Slope. It shows more clearly that FOS decreases as slope increases. 


\section{Analysis of reinforced slopes}

The inclusion of coir-fibre geotextile reinforcement has been simulated as a single restoring force acting at the point of intersection of the free-body boundary and the reinforcement plane (Ingold, 1986; Jewell, 1988; Kaniraj \& Abdullah, 1992 and 1993).

With the reinforcement $\left(T_{R}\right)$ installed at the base of an embankment, the Global Factor of Safety $\left(\mathrm{FOS}_{\mathrm{G}}\right)$ could be obtained by directly adding the restoring moment provided by the reinforcement to the resisting moment of the ground as defined in equation (1) (Mwasha, 2008).

$$
\mathrm{FOS}_{\mathrm{G}}=\mathrm{FOS}_{\mathrm{U}}+\frac{\mathrm{Y}_{\mathrm{R}}}{\mathrm{R} \sum \mathrm{W}_{\sin \alpha}}
$$

A detailed description of the terms, Y, R, W and $\alpha$, can be found in Mwasha (2008). This equation shows that the Global Factor of Safety $\left(\mathrm{FOS}_{\mathrm{G}}\right)$ can be considered to comprise two components--that due to the soil shear strength alone $\left(\mathrm{FOS}_{\mathrm{U}}\right)$ and that due to the reinforcement $\left(\mathrm{FOS}_{\mathrm{TR}}\right)$, where $\mathrm{FOS}_{\mathrm{TR}}$ is the second term on the right hand side of equation (1). If both sides of the equation are divided by $\mathrm{FOS}_{\mathrm{G}}$ it can then be rewritten as:
$1=\frac{\mathrm{FOS}_{\mathrm{U}}}{\mathrm{FOS}_{\mathrm{G}}}+\frac{\mathrm{Y}}{\mathrm{R}}\left(\frac{\mathrm{T}_{\mathrm{R}}}{\mathrm{FOS}_{\mathrm{G}}}\right) \frac{1}{\sum \mathrm{W}_{\sin \alpha}}$

Next, if $T_{R} / F S_{G}$ is defined as the reinforcement strength, $\mathrm{T}_{\mathrm{RM}}$, which has to be mobilized, the equation reduces to:

$1=\frac{\mathrm{FOS}_{\mathrm{U}}}{\mathrm{FOS}_{\mathrm{G}}}+\frac{\mathrm{Y}}{\mathrm{R}}\left(\mathrm{T}_{\mathrm{RM}}\right) \frac{1}{\sum \mathrm{W}_{\sin \alpha}}$

Equation (3) can be simplified further by combining the total disturbing moment and critical slip circle parameters Y (lever arm) and $\mathrm{R}$ (radius) into $\forall$ as follows:

$\frac{\mathrm{Y}}{\mathrm{R}} \frac{1}{\sum \mathrm{W}_{\sin \alpha}}=\forall$

giving finally

$1=\frac{\mathrm{FOS}_{\mathrm{U}}}{\mathrm{FOS}_{\mathrm{G}}}+\mathrm{T}_{\mathrm{RM}} \forall$

In this paper, equation (5) will be used to investigate the diminishing effects of reinforcement on the stability of an embankment erected on soft soil.

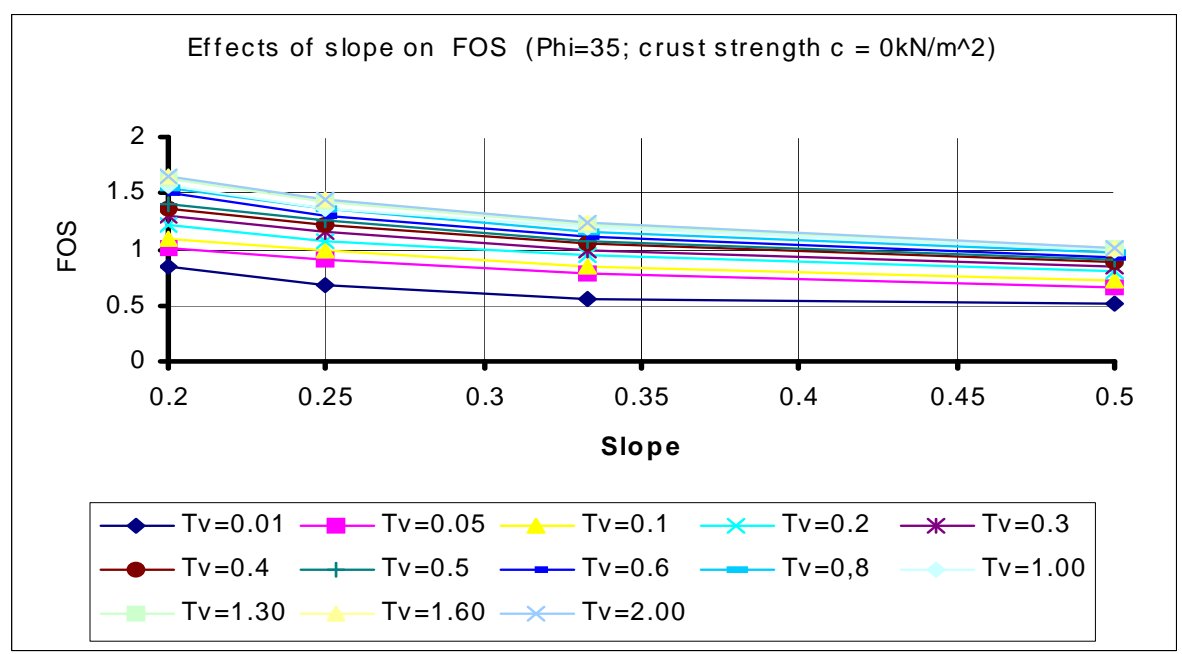

Figure 3: Stability of slopes on varying degree of consolidation. 


\section{RESULTS FOR REINFORCED SLOPES}

From equation (5) it is possible to estimate the reinforcement tensile strengths required to achieve a specific FOS for different degrees of consolidation. The results are given in Figures 4 and 5 for a global Factor of Safety $\left(\mathrm{FOS}_{\mathrm{G}}\right)$ of unity. Figure 4 shows results for the steepest slope $(1: 2)$. The required reinforcement force generally decreases with consolidation period ( $\mathrm{Tv}$ ) for all values of FOS, as expected.
Figure 5 shows results for a number of different slopes. For the 'flatter' slopes, (1:5 and 1:4), the required reinforcement force decreases from the onset of consolidation and becomes zero at small values of consolidation (approximately $25 \%$ and $38 \%$, respectively). However, for the steepest slope (1:2), when the degree of consolidation is in the range of $25 \%$ to $38 \%$ the force required is not zero, but is almost constant at approximately $50 \mathrm{kN} / \mathrm{m}$.

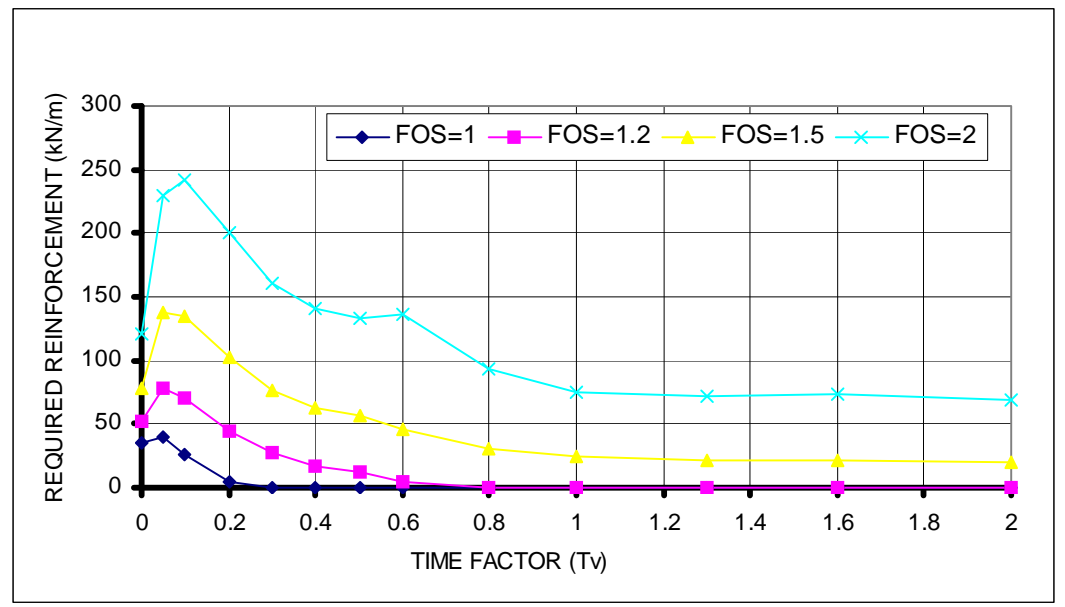

Figure 4: Effects of Time Factor on required reinforcement slope: Slope V:H = 1:2

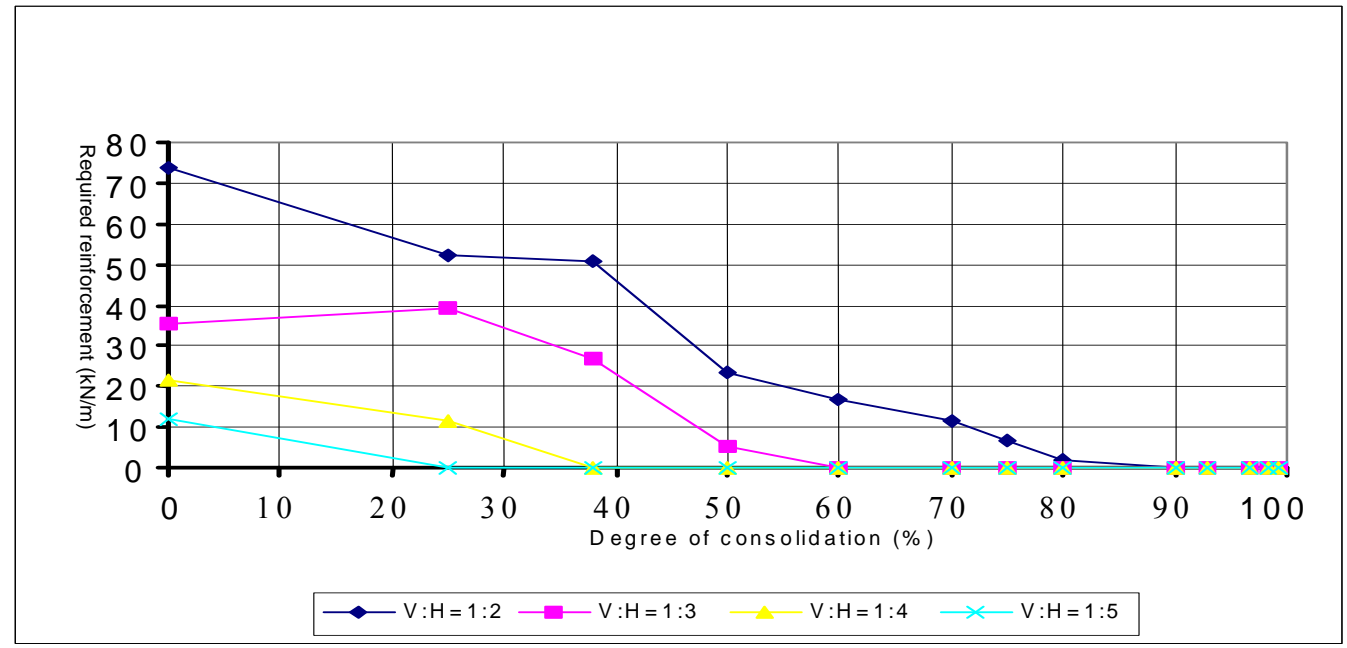

Figure 5: Effects of degree of consolidation on required reinforcement force $\left(\mathrm{FOS}_{\mathrm{G}}=1.00\right)$ 
For the mid-range 1:3 slope, the required reinforcement force actually increases slightly at the start of the consolidation process (from 0 to $25 \%$ ), and subsequently decreases progressively with degree of consolidation.

For global Factors of Safety greater than unity and slope $\mathrm{V}: \mathrm{H}=1: 3$ the same general trend is found (see Figure 6).

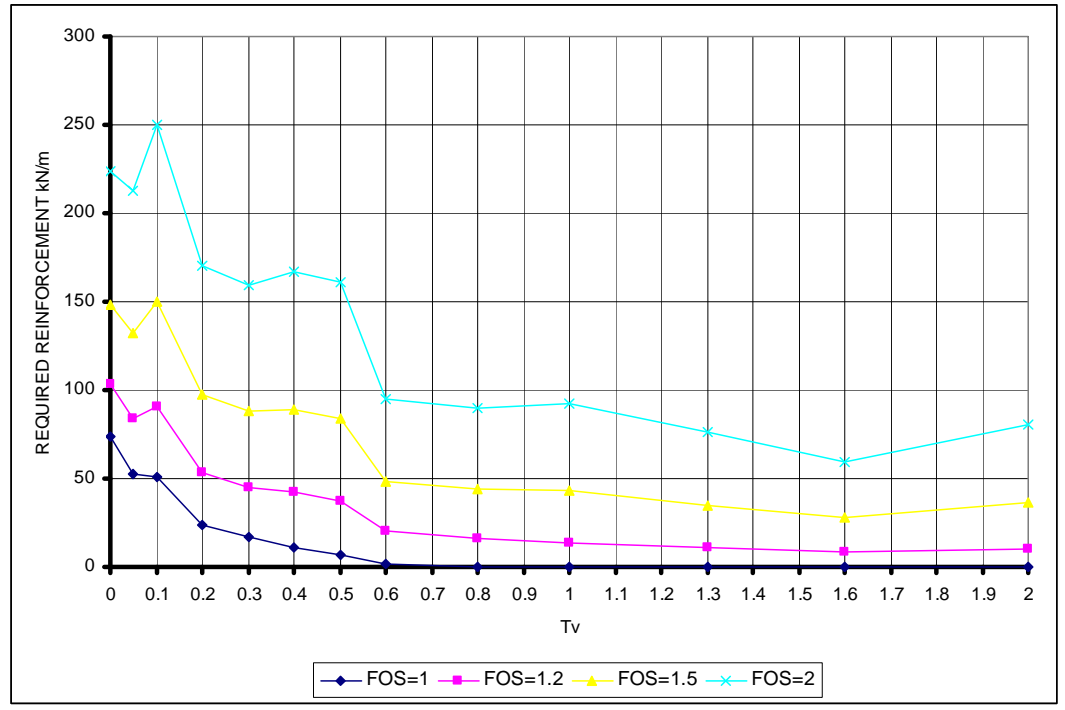

Figure 6: Effects of Time Factor on required reinforcement slope. Slope V:H= 1:3

All these results suggest that it is possible to use a biodegradable material such as coir fibre to reinforce a free drain embankment erected on soft ground.

\section{CONCLUSIONS}

From the results of this work it was possible to determine the strength of coir fibre reinforcement required to achieve a specific FOS. The analytical work conducted in this paper has shown that the stability of the embankment constructed on soft soil will improve over time as the pore pressure in the underlying soft soil dissipates and the effective stress increases. The stabilizing force (which has to be provided by the geotextile) decreases with time as the underlying soil strength simultaneously increases. The amount of required geotextiles can be selected so that the loss in strength of the geotextile due to biodegradation corresponds to the reduction in the required stabilizing force. The design concept is based on the point that the embankment and foundation soil will be stable in the long term with the geotextiles being required only to bolster short-term stability. The analytical model was successful in showing that geotextiles with limited lives, such as coir fibre, can be used, provided the strength requirement decreases with time. This model can also be used to investigate the use of different types of biodegradable fibres for ground engineering, including coir fibre obtained from coconut palms which are abundant in the Caribbean. 


\section{REFERENCES}

Anthony, M. (1997). Historical dictionary of

Trinidad and Tobago. Lanham, MD:

Scarecrow Press.

Bismarck, A., Mohanty, A. K., AranberriAskargorta, I., Czapla, S., Misra, M., Hinrichsen, G., et al. (2001). Surface characterization of natural fibers; surface properties and the water up-take behavior of modified sisal and coir fibers. Green Chemistry, 3, 100-107.

GEO5 Geotechnical Software. (1999-2007).

Retrieved May 2, 2009 from

http://www.finesoftware.eu/geotechnicalsoftware/

Holtz, R. D. (2001). Geosynthetics for soil reinforcement : The ninth Spencer J. Buchanan lecture. Retrieved May 2, 2009 from https://ceprofs.civil.tamu.edu/briaud/buchanan $\% 20 \mathrm{web} /$ lectures/ninth\%20buchanan $\% 20$ lectu re.pdf

Ingold, T. S. (1986). Analysis of geotextile reinforced embankments over soft clays. Highways and Transportation, 33(3), 3-8.

Jewell, R. A. (1988). The mechanics of reinforced embankments on soft soils. Geotextiles and Geomembranes, 7(4), 237-273.

Jones, C. J. F. P. (1996). Earth reinforcement and soil structures. London: Thomas Telford.

Kaniraj, S. R., \& Abdullah, H. (1992). Stability analysis of reinforced embankments on soft soils. Journal of Geotechnical Engineering, 118(12), 1994-1999. doi:

10.1061/(ASCE)0733-

9410(1992)118:12(1994)

Kaniraj, S. R., \& Abdullah, H. (1993). Rotational stability of narrow-crested reinforced embankments on soft soils. Geotextiles and Geomembranes, 12(7), 599-614. http://eprint.iitd.ac.in/dspace/handle/2074/231 7

Mwasha, A. (2003). Time dependent behaviour of embankment reinforced with limited life geotextiles. In D. Proverbs (Ed.), COBRA 2003: Proceedings of the RICS Foundation Construction and Building Research Conference (pp 456-469). London: RICS
Foundation. Retrieved May 2, 2009 from http://www.rics.org/NR/rdonlyres/27B5E0E2755A-40D3-BA0E-

B314F5335C49/0/limited_life_geotextiles.pdf

Mwasha, A. (2005). Limited life basal reinforcement for an embankment built on saturated soft clay. Unpublished doctoral dissertation, University of Wolverhampton, England.

Mwasha, A. (2006). Authenticity on applications of Terzhagi's deferential equation for the estimation of pore water pressure.

Mathematics and its Applications, Institute of Critical Thinking, University of the West Indies.

Mwasha, A. (2008). Using environmentally friendly geotextiles for soil reinforcement: A parametric study. Materials \& Design, 30(5), 1798-1803. doi:

10.1016/j.matdes.2008.07.018.

Pritchard, M. (1999). Vegetable fibre geotextiles. Unpublished doctoral thesis, Manchester University, Bolton Institute, England.

Vogel, M. N. (2004). Up against the wall: An archaeological field guide to bricks in Western New York. Retrieved May 2, 2009 from: http://www.buffaloah.com/a/DCTNRY/mat/br $\mathrm{k} /$ vogel/index.html

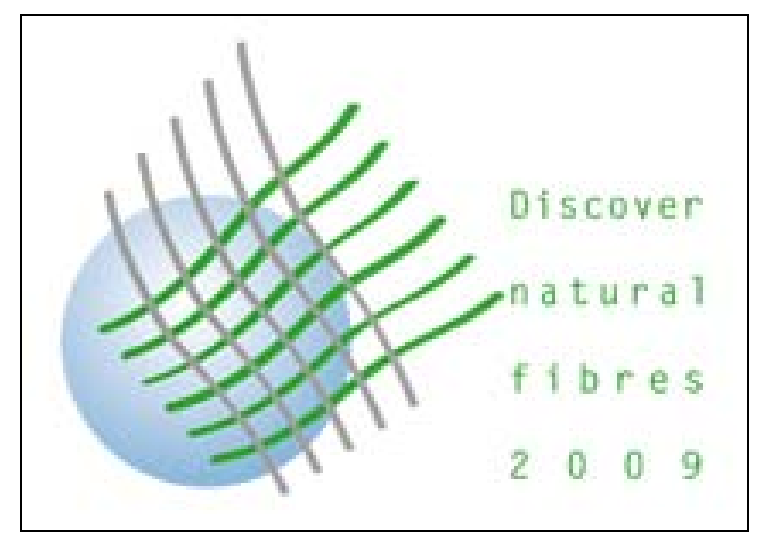

International Year of Natural Fibres, 2009 